\title{
Urgences
}

\section{Tableau périodique des éléments}

\section{Claude Robitaille}

Numéro 15, octobre 1986

Épigraphiques

URI : https://id.erudit.org/iderudit/025309ar

DOI : https://doi.org/10.7202/025309ar

Aller au sommaire du numéro

\section{Éditeur(s)}

Urgences

\section{ISSN}

0226-9554 (imprimé)

1927-3924 (numérique)

Découvrir la revue

\section{Citer ce document}

Robitaille, C. (1986). Tableau périodique des éléments. Urgences, (15), 43-43.

https://doi.org/10.7202/025309ar d'utilisation que vous pouvez consulter en ligne.

https://apropos.erudit.org/fr/usagers/politique-dutilisation/ 


\title{
Claude Robitaille TABLEAU PÉRIODIQUE DES ÉLÉMENTS
}

\author{
J'aime ce qui est littéraire et parfois cela me \\ perd. \\ Julio Iglesias: Entre le ciel et l'enfer
}

les fumées montent vers la source ronde des femmes. non sans tiédir, je monte aussi, sous la charge blanche "venue du large et des bateaux". "don't turn you back on me, babe" module le soliste brésilien, stimulé par les bongos et la foule en mouvement. il y a bien une centaine de corps emportés par la samba sur le terrazzo, que cherchent à désaltérer une dizaine de serveurs. j'attends shiva à une table en retrait, qui m'y a donné rendez-vous avec une insistance posologique inédite: "écoute, quand j'ai l'goût de donner, prends, hésite pas". sous sa robe chimique, une collecte de fruits qui rendent addict. sans perdre de vue la piste de danse, je surveille la progression du terrorisme dans le monde et le démantèlement des laboratoires boliviens sur une télé miniature rivée à même la table - lorsqu'elle se pointe. elle apporte (tel que prévu) la disquette où dorment, magnétisés, les premiers chapitres de son livre des matières. "c'est parce que j'en suis à l'étape des matières joyeuses que j'ai voulu te voir" qu'elle me précise, consciente elle aussi des lumières qui lèvent. dans la toilette des handicapés, il y a foule autour d'un joint. 